\title{
ANALIZA ODCISKÓW TKANIN \\ NA IX-XI-WIECZNEJ CERAMICE NACZYNIOWEJ Z GÓRY, GM. POBIEDZISKA, WOJ. WIELKOPOLSKIE, STAN. 1
}

\author{
AN ANALYSIS OF FABRICS IMPRESSIONS \\ ON POTTERY FROM THE $9^{\text {TH }}$ TO $11^{\text {TH }}$ CENTURY FROM GÓRA, \\ SITE 1, POBIEDZISKA COMMUNE, WIELKOPOLSKA VOIVODESHIP
}

\author{
Andrzej Sikorski \\ Instytut Prahistorii, Uniwersytet im. Adama Mickiewicza \\ ul. Św. Marcin 78, 61-809 Poznań, Poland
}

ABSTRACT. Results of the analysis of fabrics impressions on pottery brings about a valuable information about materials used in potter's workshops. It seems that old rags were most commonly used there. Craftsmen employed them for the following purposes: (a) to get a molded vessel unstuck from pad and/or wheel (the rag was put under the bottom - possibly instead of filling); (b) to smooth vessel's surface (after it has been formed); (c) to carry finished, albeit still soft pot; (d) to put a drying vessel on the fabric. A study of "pottery" fabrics, often completely ignored by scholars, is not of trivial importance for the reconstruction of textile products, not only in the Middle Ages.

Coraz częściej - podczas techno-stylistycznej analizy materiału ceramicznego dokonuje się przypadkowych, acz interesujących, odkryć odcisków tkanin, „utrwalonych" na wyrobach ceramicznych ${ }^{1}$. Obserwacje i badanie tej kategorii znalezisk były prowadzone dotąd na małą skalę 2 .

Przypadkowe i/lub intencjonalne negatywy tekstyliów (na naczyniach, przęślikach, grzęzidłach lub kaflach) ${ }^{3}$ stanowią - pomimo określonych zastrzeżeń ${ }^{4}$ - uzupełnienie danych o asortymencie tkanin pradziejowych, średniowiecznych i nowo-

\footnotetext{
${ }^{1}$ Wdzięczny jestem mgr Oldze Antowskiej za udostępnienie materiałów ceramicznych, dokumentacji i wykonanie rycin.

${ }^{2}$ Dąbrowski 1999, s. 52.

${ }^{3}$ Sikorski 2000, s. $143-152$.

${ }^{4}$ Sikorski 1998, s. 191.
} 
żytnych, tym bardziej że wyroby włókiennicze - jeśli już - zachowują się raczej szczątkowo w inwentarzach osadowych i w grobach ${ }^{5}$.

Od kilku lat w Instytucie Prahistorii UAM w Poznaniu prowadzone są badania nad utrwalonymi na wyrobach ceramicznych negatywami tekstyliów, które zaliczyć należy do grupy tkanin ,produkcyjnych”, zapewne wykorzystywanych w warsztatach garncarskich jako (częściowo zużyte) gorsze gatunkowo szmaty.

Zwykle - jak wolno przypuszczać - rzemieślnik stosował je w celu: (-) łatwiejszego odklejenia od podkładki i/lub koła ulepionego naczynia (podłożenie tkaniny pod dno - może zamiast podsypki?); (-) wyrównania powierzchni ścianki (po uformowaniu bryły naczynia); (-) przenoszenia gotowego, plastycznego jeszcze pojemnika (z użyciem szmaty); (-) ustawienia na tkaninie schnącego naczynia.

Każda z wymienionych czynności była jak najbardziej intencjonalna, jakkolwiek nie można wykluczyć śladów przypadkowych odcisków roboczej odzieży garncarza(-ki) (fartuch, gacie, ,casula”, płachacica).

Seria tkanin $-z$ warstw i obiektów - jest nieliczna. Obserwacja odcisków na ceramice w znacznym stopniu poszerza źródła, a w konsekwencji możliwości interpretacji i rekonstrukcję asortymentu wyrobów włókienniczych nie tylko z okresu wczesnego średniowiecza ${ }^{6}$.

\section{LOKALIZACJA STANOWISKA ARCHEOLOGICZNEGO}

Odciski tkanin zaobserwowane na ułamkach naczyń pochodzą z osady wczesnośredniowiecznej, wchodzącej w skład stanowiska wielokulturowego, które zlokalizowano na wyspowatym wzniesieniu, przylegającym od południa bezpośrednio do brzegu jeziora Góra, od wschodu zaś i od północy otoczonym korytem rzeki Cybiny, a od zachodu pasmem mokradel ${ }^{7}$. Piaszczysty pagórek zajmuje powierzchnię około 1,8 ha, stanowiac nad wyraz dogodne miejsce dla osadnictwa od mezolitu po czasy nowożytne (ryc. 1).

\section{OMÓWIENIE WYNIKÓW ANALIZY}

Tylko na dwóch ułamkach garnków, głównie na zewnętrznej powierzchni ścianki i dnie, stwierdzono odciski tkanin. Fragmenty czerepów zapewne pochodzą z rozbitych pojemników częściowo i/lub całkowicie obtaczanych (GT II/III) i całkowicie obtaczanych na kole garncarskim (GT III) ${ }^{8}$. Niestety, fragmenty z negatywa-

\footnotetext{
${ }^{5}$ Maik 1988.

${ }^{6}$ Sikorski 1998, s. 191-195.

${ }^{7}$ Kócka-Krenz i Sikorski 1992, s. 135-148: 1995, s. 93-106.

${ }^{8}$ Sikorski 1995, s. 98-111.
} 


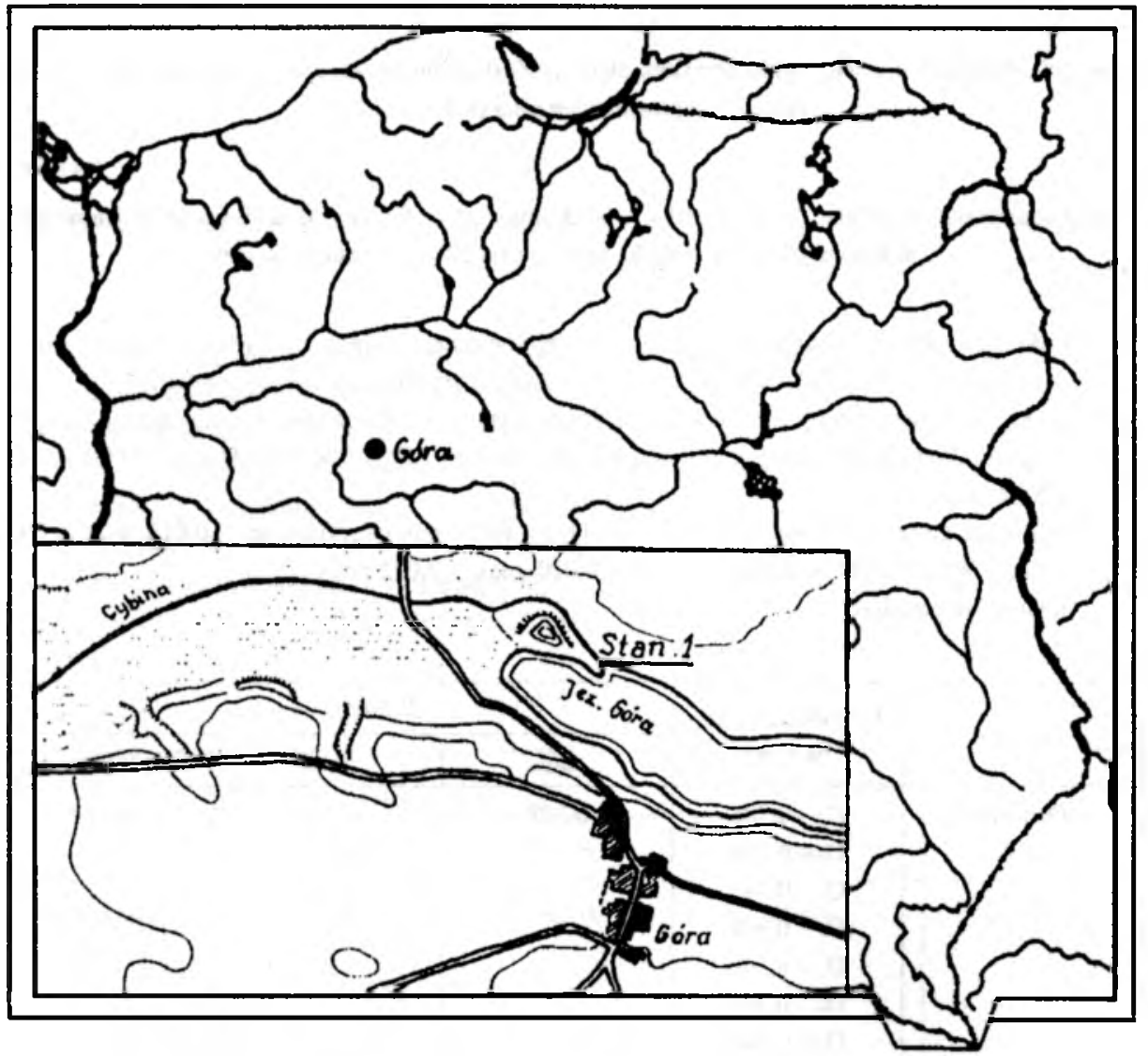

Ryc. 1. Góra, gm. Pobiedziska, woj. wielkopolskie, stan. 1. Lokalizacja stanowiska. Rys. M. Gorączniak

Fig. I. Góra, Pobiedziska commune, Wielkopolska voivodeship, site 1. Site's location. Drawn by M. Gorączniak

mi tekstyliów zalegały w I (wykop 2, na kulminacji - tab. 1; ryc. 2: 3) i II warstwie naturalnej (wykop 34, wyraźna niecka terenowa w północno-wschodniej części stanowiska - tab. 2; ryc. 2: 4). Niewielkie, mało diagnostyczne kawałki naczyń (III i IV grupa wielkościowa $)^{9}$, stosując ogólne kryteria techno-stylistyczne, zaliczono do form IX-X w. (wykop 34) i X-XI w. (wykop 2).

Zachowane negatywy poddano rutynowym analizom makro- i mikroskopowym. Ekspertyzy wykonano pod kierunkiem dra Adama Głazaczowa z Instytutu Badań Środowiska UAM w Poznaniu. Wykonano łącznie 65 pomiarów laboratoryjnych. Wy-

\footnotetext{
${ }^{9}$ Buko 1990, s. 235-244.
} 
Tabela 1

Góra, gm. Pobiedziska, woj. wielkopolskie, stan. 1. Zestawienie wyników analiz odcisku fragmentu tkaniny na powierzchni naczynia z X-XI w.

Table 1

Góra, Pobiedziska commune, Wielkopolska voivodeship, site 1. Results of analyses of an imprint of a fragment of a fabric on the surface of a $10^{\text {th }}-11^{\text {th }}$ century vessel

1. Analiza odcisku fragmentu tkaniny na zewnętrznej ściance naczynia; wymiary próbki: $1,3 \times 0,5 \mathrm{~cm}$ (mniej wyraźne negatywy na wewnętrznej powierzchni pojemnika).

2. Odcisk z górnej części zdobionego brzuśca naczynia - GT III (wypał w atmosferze utleniającej. kolor faktury zewnętrznej ścianki brązowy (o odcieniu 7.5YR 5/4, 5/5 - Munsell 1973).

3. Surowiec: ?

4. Średnia grubość włókna elementarnego: $\mathrm{O}_{\mathrm{l}-5}-0,020 \mathrm{~mm}$ (wartość min. $-0,018, \max .-0,020$ $\mathrm{mm}$ ); $\mathrm{W}_{1-5}-0,021 \mathrm{~mm}$ (wartość min. $-0,020$, max. $-0,022 \mathrm{~mm}$ ).

5. Grubość przędzy:

\begin{tabular}{|c|c|c|c|c|}
\hline \multirow{2}{*}{ Przędza } & \multirow{2}{*}{$\begin{array}{c}\text { Grubość przędzy } \\
\text { (w mm) }\end{array}$} & \multicolumn{3}{|c|}{ Wartości (w mm) } \\
\hline & & $\min$. & $\max$ & średnia \\
\hline Osnowa & $\begin{array}{l}\mathrm{O}_{1}-0,308 \\
\mathrm{O}_{2}-0,308 \\
\mathrm{O}_{3}-0,346 \\
\mathrm{O}_{4}-0,308 \\
\mathrm{O}_{5}-0,346 \\
\mathrm{O}_{6}-0,346 \\
\mathrm{O}_{7}-0,346 \\
\mathrm{O}_{8}-0,308 \\
\mathrm{O}_{9}-0,308 \\
\mathrm{O}_{10}-0,346\end{array}$ & 0,308 & 0,346 & 0,327 \\
\hline Wątek & $\begin{array}{l}W_{1}-0,385 \\
W_{2}-0,385 \\
W_{3}-0,423 \\
W_{4}-0,385 \\
W_{5}-0,423 \\
W_{6}-0,423\end{array}$ & 0,385 & 0,423 & 0,404 \\
\hline
\end{tabular}

5a. Pomiar równomierności przędzy: ?

6. Skręt: ZZ

7. Splot płócienny 1/1; tkanina nie spilśniona ?; typ 1 (Maik 1988, s. 62-65).

8. Gęstość tkaniny: $\mathrm{O}-14 ; \mathrm{W}-12 \mathrm{nici} / \mathrm{cm}^{2}$ (gatunek III).

9. Datowanie: $\mathrm{X}-\mathrm{XI}$ w.

10. Nr inw. $\mathrm{G}_{1} / 59 / 86$ (w-wa I - wykop 2).

11. Uwagi: śladowo zachowały się zagładzania wewnętrznej powierzchni ścianki naczynia. 
Tabela 2

Góra, gm. Pobiedziska, woj., wielkopolskie, stan. 1. Zestawienie wyników analiz odcisku fragmentu tkaniny na dnie naczynia $\mathrm{z} I X-X \mathrm{w}$.

Table 2

Góra, Pobiedziska commune, Wielkopolska voivodeship, site 1. Results of analyses of an imprint of a fragment of a fabric on the surface of a $9^{\text {th }}-10^{\text {th }}$ century vessel

1. Analiza odcisku fragmentu tkaniny; negatyw płytki, słabo czytelny, ,ciagnnięty” ku zewnętrznej części dna; wymiary próbki: $1 \times 1,3 \mathrm{~cm}$.

2. Odcisk na dnie (obrzeże) - GT II/III; średnica dna $12,5 \mathrm{~cm}$, grubość $1,5 \mathrm{~cm}$; negatyw w niewielkim zagłębieniu (wypał w atmosferze utleniającej, kolor faktury zewnętrznej ścianki żółtobrązowy, o odcieniu 10YR 5/3, 5/4 - Munsell 1973).

3. Surowiec: ?

4. Średnia grubość włókna elementarnego: $\mathrm{O}_{1-5}-0,024 \mathrm{~mm}$ (wartość min. $-0,021$, max. $-0,026 \mathrm{~mm}$ ); $\mathrm{W}_{\mathrm{l}-5}-0,024 \mathrm{~mm}$ (wartość min. $-0,021$, max. $-0,026 \mathrm{~mm}$ ).

5. Grubość przędzy:

\begin{tabular}{|c|c|c|c|c|}
\hline \multirow{2}{*}{ Przędza } & \multirow{2}{*}{$\begin{array}{c}\text { Grubość przędzy } \\
(\mathrm{w} \text { mm })\end{array}$} & min. & max. & średnia \\
\cline { 3 - 5 } & & 0,702 & 0,754 & 0,723 \\
\hline \multirow{2}{*}{ Osnowa } & $0_{1}-0,702$ & & & \\
& $0_{2}-0,728$ & & & \\
& $0_{3}-0,754$ & & & \\
& $0_{4}-0,702$ & & 0,905 \\
& $0_{5}-0,728$ & & & \\
\hline \multirow{2}{*}{ Wątek } & $\mathrm{W}_{1}-0,806$ & 0,806 & & \\
& $\mathrm{~W}_{2}-0,962$ & & & \\
& $\mathrm{~W}_{3}-0,910$ & & & \\
& $\mathrm{~W}_{4}-0,910$ & & & \\
& $\mathrm{~W}_{5}-0,936$ & & & \\
\end{tabular}

\section{Pomiar równomierności przędzy: ?}

6. Skręt: ZZ

7. Splot płócienny 1/1; tkanina nie spilśniona?; typ 1 (Maik 1988, s. 62-65).

8. Gęstość tkaniny: $\mathrm{O}-10 ; \mathrm{W}-8 \mathrm{nici} / \mathrm{cm}^{2}$ (gatunek IV).

9. Datowanie: IX-X w. ?

10. $\mathrm{Nr}$ inw. G $\mathrm{G} / 51 / 98$ (w-wa IIa - wykop 34).

11. Uwagi: na powierzchni zewnętrznej ślady okopceń, wewnątrz wyrównywania i/lub zastosowania drewnianego narzędzia do modelowania dna i części przydennej; pozostałości zwęglonych organików? 
niki i wnioski, jakie udało się sformułować na podstawie analiz dwóch próbek, omówione będą zgodnie ze schematem wytwórczym i obejmują prawie wszystkie czynności związane z przygotowaniem przędzy i tkaniem. Dokonano także hipotetycznej oceny umiejętności tkacza, który - niezależnie od przeznaczenia materiału wykonał ów wyrób włókienniczy.

Niewielka powierzchnia negatywów $\left(0,65-1,3 \mathrm{~cm}^{2}\right)$, płytkie, częściowo zatarte odciski, w zasadniczy sposób ograniczają analizę, zniekształcając - w pewnym zakresie - wyniki pomiarów.

\section{SUROWCE WLÓKIENNICZE}

Dysponując odciskami fragmentów tkaniny możemy jedynie domniemywać, że materiał utkano $\mathrm{z}$ wełny. Niestety, nie zachowały się żadne ślady spieczonych substancji organicznych, jakie - w innych przypadkach - udawało się rejestrować $w$ utrwalonych negatywach tkaniny ${ }^{10}$. Pomimo zasygnalizowanych utrudnień dokonano serii orientacyjnych dziesięciu pomiarów włókien elementarnych, które miały grubość w granicach: 0,020/0,024 mm (w osnowach) - 0,021/0,024 mm (w wątkach). Naturalnie, wyniki te w niewielkim stopniu odwzorowują pierwotne średnice włókien, z których skręcono przędzę osnowy (O) i wątku (W). Można zakładać, iż ich średnice zmniejszyły się, ulegając dalszej deformacji pod wpływem szoku termicznego $w$ trakcie wypału i bezpośredniego użytkowania pojemnika.

Surowiec włókienniczy odciśnięty na góreckiej ceramice może być zestawiany z wynikami pomiarów wykonanymi m.in. dla serii „klasycznych” próbek z Santoka (VII/VIII - 1. polowa IX w.), Wolina (IX-XIII w.), Kamienia Pomorskiego (XXII w. $)^{11}$, jak również z ceramicznymi próbkami z Nowej Wsi (VII-VIII w.) ${ }^{12}$. Szczątkowo zachowane, do tego przeobrażone włókna elementarne (wypał i/lub eksploatacja naczynia), które odcisnęły się w spodniej części negatywu, stwarzają istotną przeszkodę przy określeniu nierównomierności surowca i potwierdzenia w nim (lub nie) włosów np. zwierząt futerkowych, bydła, ludzi i - być może - włókien $\operatorname{lnu}^{13}$.

\section{PRZĘDZA}

W obydwóch przypadkach przędza wełniana (?) skręcana była w prawo (ZZ) tab. 1, 2 (nici w skręcie $Z$ należą do bardzo popularnych w średniowieczu). Wyniki pomiarów grubości przędzy odciśniętej na garnkach z Góry dowiodły, że w obydwóch systemach tkania rygorystycznie przestrzegano zasady wykorzystania cieńszej

\footnotetext{
${ }^{10}$ Sikorski 1998, s. 191, 192.

${ }^{11}$ Maik 1988, s. 51.

${ }^{12}$ Sikorski 1998, s. 192, 193.

${ }^{13}$ Niesiołowska-Wędzka 1965, s. 320; Maik 1988, s. 53.
} 


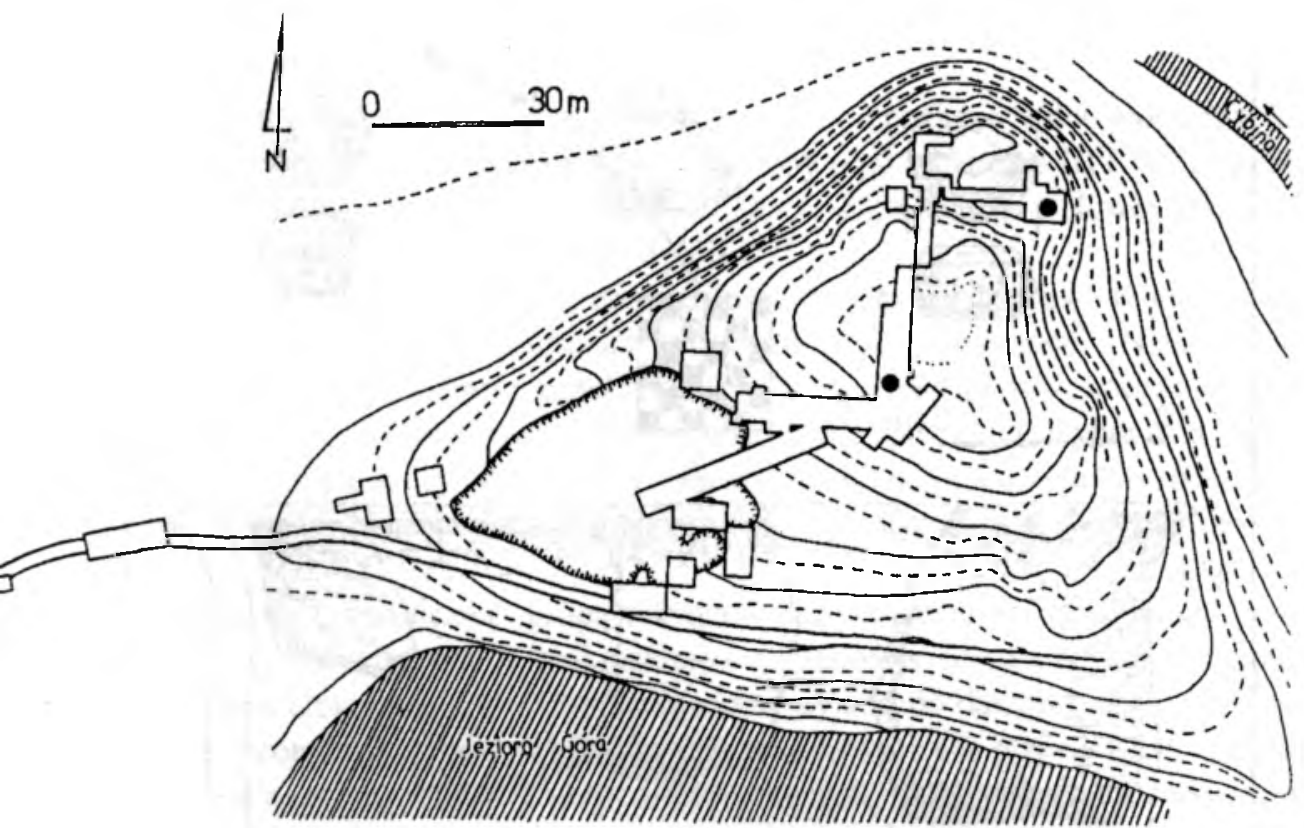

Ryc. 2. Góra, gm. Pobiedziska, woj. wielkopolskie, stan. 1. Rozplanowanie wykopów, z zaznaczeniem miejsc znalezienia ułamków ceramiki z odciskami tkanin. Rys. O. Antowska

Fig. 2. Góra, Pobiedziska commune, Wielkopolska voivodeship, site 1. Trenches' location with marked places in which pottery fragments with fabrics impressions have been found. Drawn by $O$. Antowska

przędzy w osnowach, grubszej zaś w wątku. Pomimo poczynionych zastrzeżeń, na góreckich próbkach ceramicznych rozpoznano negatywy cienkich (tab. 1) i grubszych nici (tab. 2). Średnia grubość przędzy odciśniętej na naczyniu z X-XI w. waha się w granicach $0,327(\mathrm{O})-0,404 \mathrm{~mm}(\mathrm{~W})$, natomiast na konwencjonalnie starszym pojemniku - datowanym na IX-X w. - między $0,723(\mathrm{O})$ a $0,905 \mathrm{~mm}(\mathrm{~W})$. Wyniki analizy tej cechy technicznej, decydującej o jakości materiału, porównywalne są z obliczeniami poczynionymi dla zbiorów Santoku, Wolina, Kamienia Pomorskiego, częściowo Gdańska $^{14}$, Dziekanowic ${ }^{15}$ i Giecza $^{16}$. Nasze obserwacje poniekąd potwierdzają zasadę stosowania - począwszy od XI w. - cieńszej przędzy ${ }^{17}$. Na podstawie średnich wartości obliczonych dla nici $\mathrm{O}$ i W można je uznać za wystarczająco dobre, a zastosowanie równokierunkowej przędzy (ZZ) gwarantowało uzyskanie jednorodnej faktury materiału.

\footnotetext{
${ }^{14}$ Maik 1988, ryc. 78.

${ }^{15}$ Sikorski, Wrzesińska, Wrzesiński 1988, s. 71-94.

${ }^{16}$ Sikorski (w druku).

${ }^{17}$ Maik 1988, s. 120.
} 


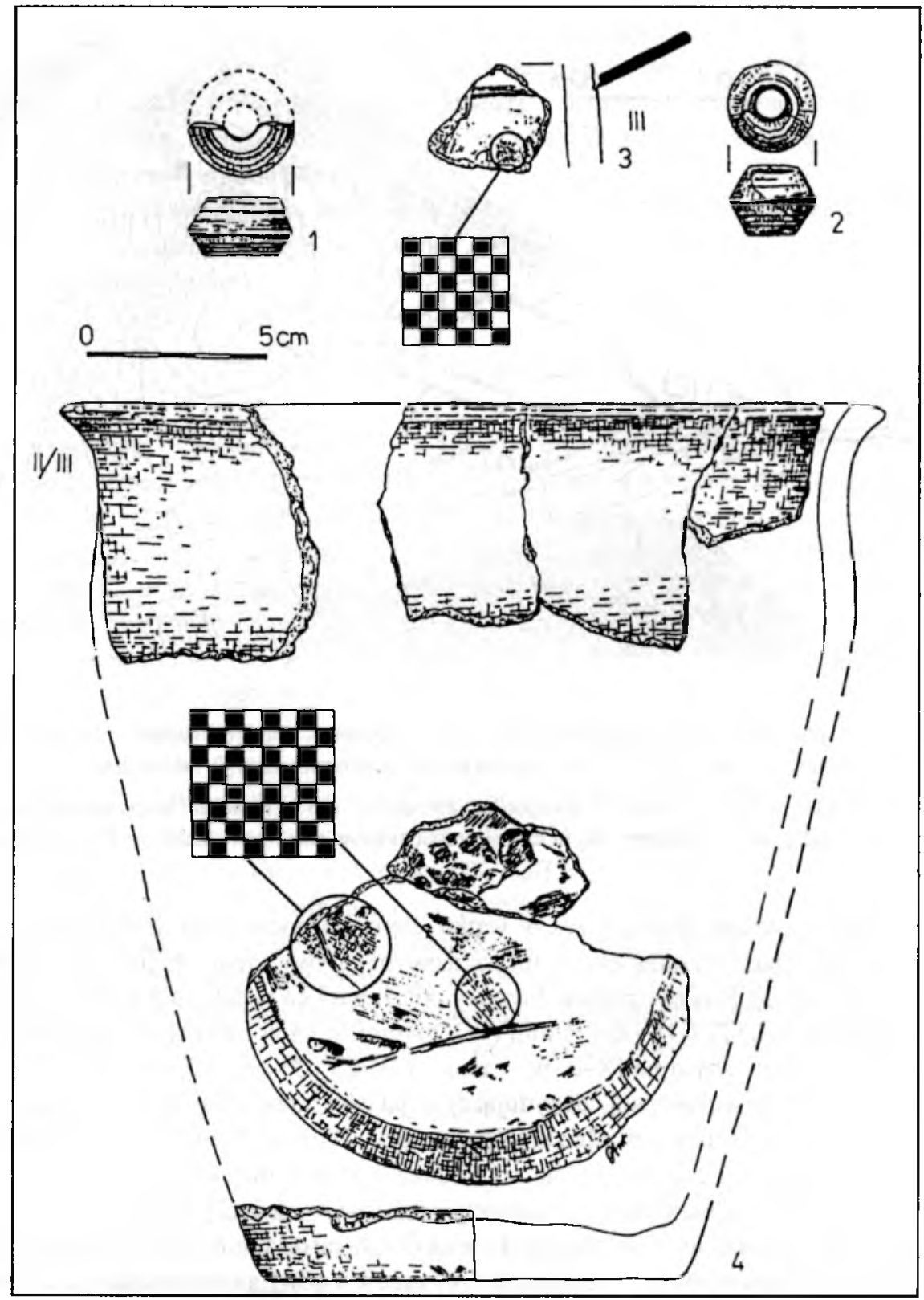

Ryc. 3. Góra, gm. Pobiedziska, woj. wielkopolskie, stan. 1. Wybór materiałów ruchomych, związanych z tkactwem: 1,2 - przęśliki gliniane; 3,4-fragmenty naczyń z negatywami tkanin z wykopu 2 (GT III) i wykopu 34 (GT I//II). Rys. O. Antowska

Fig. 3. Góra, Pobiedziska commune, Wielkopolska voivodeship, site 1. A selection of artifacts related to textile production: 1,2 - spindle whorls; 3,4-fragments of vessels with fabrics negatives from trench 2 (GT III) and 34 (GT II/II). Drawn by O. Antowska 


\section{TKANINA}

$\mathrm{Na}$ analizowanych negatywach ceramicznych rozpoznano splot płócienny $1 / 1$ (ryc.2: 3,4 ). Przypuszczalnie więc były to wyroby typu 1 gatunku III i IV ${ }^{18}$. Podobnie tkane materiały znamy m.in. z Wolina (IX-X w.), Gdańska i Nowej Wsi, chociaż najstarsze okazy pochodzą już z VI-VII w. ${ }^{19}$

Omawiane próbki odnoszą się do dwóch, najgorszych gatunkowo tkanin, co nie najlepiej świadczy o umiejętnościach warsztatowych wytwórców ${ }^{20}$. Niestety, nie odcisnęły się żadne „diagnostyczne” elementy (brzeg początkowy, boczny, końcowy), na podstawie których można by rekonstruować sposób ich wykonania. Pozostaje otwarta kwestia: czy odciśnięte fragmenty utkano na pionowym krośnie ciężarkowym, czy na krosienkach tabliczkowych, znajdujących zastosowanie jeszcze w XII w.?

Studia nad „ceramiczną” grupą tekstyliów, często zupełnie ignorowaną przez badaczy na poziomie analizy makroskopowej zespołów ceramicznych, przynoszą już określone efekty naukowe, stanowiąc punkt wyjścia do dalszych prób, co - wobec ograniczonych zasobów organicznych tekstyliów - ma przecież niebagatelne znaczenie dla rekonstrukcji wyrobów włókienniczych, zachowanych szczątkowo na osadach, w grodach, miastach i na cmentarzyskach (gdzie często m.in. znajdowane są przęśliki - ryc. 2: 1,2). Ciągle niewiele wiemy o „modach”, dystrybucji i poziomie rzemiosła włókienniczego $\mathrm{w}$ wymiarze lokalnym lub w skali międzyregionalnej. Najgorsza - z dzisiejszego punktu widzenia - kategoria szmat wykorzystywanych w warsztacie garncarza (zduna) czeka na pełniejsze opracowanie, które - w przyszłości - będzie mogło uzupełnić pewne luki w zakresie poznania zarówno średniowiecznego tkactwa (stojącego przecież - co wiemy na podstawie źródeł pisanych - na wysokim poziomie) $)^{21}$, jak i garncarstwa.

\section{LITERATURA}

A non im tzw. Gall.

1965 Kronika Polska (przeł. R. Grodecki), Wrocław - Warszawa - Kraków.

B u k o A.

1990 Ceramika wczesnopolska. Wprowadzenie do badań [Sum. Introduction into Research of the Early Medieval Polish Pottery], Wroclaw - Warszawa - Kraków - Gdańsk - Łódź.

${ }^{18}$ Maik 1988 , s. $62-65$.

${ }^{19}$ Maik 1988, s. 63.

${ }^{20}$ Tkacze potrafili wytwarzać gatunkowo lepsze materiały, natomiast $w$ pracowniach garncarskich wykorzystywano zapewne gorsze, przetarte już tkaniny.

${ }^{21}$ Długosz 1962, s. 300; Anonim 1965, s. 21-23; Trawkowski 1985, s. 67-86; Cuda 1997, s. $211-$ 212; Strzelczyk 2000, s. 118, 119. 
Cuda

1997 Cuda Św. Wojciecha (przekład J. Plezia), wstęp i komentarz M. Plezia, (w:) W kręgu żywotów św. Wojciecha, Kraków, s. 201-213.

Dąbrowski E.

1999 Obraz gospodarki wczesnośredniowiecznych Stowian Zachodnich w poglqdach nauki niemieckiej $i$ polskiej [Zus. Wirtschaftsbild der Frühmittelalterlichen Westslaven in den Anschaugen der Deutschen und der Polnischen Wissenschaft], Rocznik Lubuski, t. XXV, s. $35-67$.

D f u g o s z J.

1962 Jana Dtugosza Roczniki czyli Kroniki Stawnego Królestwa Polskiego, ks. I-II, Warszawa.

K óćk a-K renz H., S i korski A.

1992 Góra, gin. Pobiedziska, woj. poznańskie, stan. 1. Wstępne wyniki badań z lat 1985-1991 [Zus. Góra, Gem. Pobiedziska, Woiwodschaft Poznań, Fst. 1 - vorlaufige Ausgrabungsergebnisse aus den Jahren 1985-1991], Wielkopolskie Sprawozdania Archeologiczne, t. I, Poznań, s. 135-148.

1995 Wyniki badań średniowiecznego zespołu osadniczego w Górze, gm. Pobiedziska, woj. poznańskie, stan. 1, w 1993 i 1994 r. [Zus. Ergebnisse der Ausgrabungen in einem Mittelalterlichen Siedlungskomplex in Góra, Gem. Pobiedziska, Woi. Poznań (Fst. 1) im Jahre 1993 und 1994], Wielkopolskie Sprawozdania Archeologiczne, t. III, Poznań, s. 93-106.

Maik J.

1988 Wyroby wlókiennicze na Pomorzu z okresu rzymskiego i ze średniowiecza [Sum. The Textiles of Pomerania in the Roman Period and in the Middle Ages], Wrocław - Warszawa - Kraków - Gdańsk - Łódź.

Munsell

1973 Munsell Soil Color Charts, Baltimore.

$\mathrm{Nies}$ i olowska-Wę d zka A.

1965 Wyniki badań nad tkaninami z najstarszych warstw grodu $w$ Santoku [Rés. Résultats des recherches sur les tissus découverts dans les plus anciennes couches du Castrum de Santok], Archeologia Polski, t. X, z. 1, s. 318-337.

Sikorski A.

1995 Ceramika naczyniowa z Łekna, stanowisko nr 3 (wykopy VIII i IX) [Sum. Pottery from Łekno, stand 3 (Excavation VIII and IX)], (w:) Studia i materiaty do dziejów Patuk (red. A.M. Wyrwa), Poznań, s. 95-120.

1998 Wyniki analiz fragmentów tkanin odciśniętych na ceramice z osady wczesnośredniowiecznej w Nowej Wsi, st. 12 (43a), (w:) Archeologiczne badania ratownicze wzdtuż trasy gazociagu tranzytowego, t. I, Ziemia Lubuska (red. R. Mazurowski), Poznań, s. 191-195.

2000 Odciski tkanin na renesansowym kaflu z Lekna [Sum. Cloth Imprints on a Renaissance Stove-Tile from Łekno], Archaeologia Historica Polona, t. 8, s. 143-152.

w druku Wyniki analiz fragmentów tkanin z cmentarzyska wczesnośredniowiecznego w Gieczu (stan. 4), Studia Lednickie, t. VII.

Sikorski A., Wrzesińska A., Wrzesiński J.

1988 Tkaniny z grobów [Zus. Gewebe aus den Grabern des Frühmittelalterlichen Skelettgraberfelds in Dziekanowice, Fst. 22], Studia Lednickie, t. V, s. 71-94.

Strzelczyk J.

2000 Otton III, Wrocław - Warszawa - Kraków.

Trawkowski S.

1985 Ubiór i pielęgnacja ciala, (w:) Kultura Polski średniowiecznej X-XIII w. (red. J. Dowiat), Warszawa, s. 67-86. 


\title{
AN ANALYSIS OF FABRICS IMPRESSIONS \\ ON POTTERY FROM THE $9^{\mathrm{TH}}$ TO $11^{\mathrm{TH}}$ CENTURY FROM GÓRA. SITE 1 , POBIEDZISKA COMMUNE, WIELKOPOLSKA VOIVODESHIP
}

\author{
Sum m ary
}

A study of fabrics negatives transcribed on pottery has been conducted in the Institute of Prehistory, Adam Mickiewicz University in Poznan for several years. These materials are believed to be "production" fabrics, possibly those used in potter's workshop as (partly used) rags.

Fabrics discovered from layers and features are very limited. Thus, observation of impressions on pottery to a large extent broadens archaeological sources, and, as a result, possibilities of interpretation and reconstruction of a variety of textile production, not only in the Middle Ages. Analyzed pottery fragments come from the early medieval fully-turned and turned only in the upper part vessels (GT II/III) and fully-turned vessels on potter's wheel (GT III). On the basis of technological and stylistic criteria these vessels are included to forms dated to the $9^{\text {th }}$ and $10^{\text {th }}$ (tab. $2 ;$ fig. $2: 4$ ) and to the $10^{\text {th }}$ to $11^{\text {th }}$ centuries (tab. 1; fig. $2: 3$ ).

Preserved fragments have been analyzed macro- and microscopically. These expert appraisements have been undertaken under the supervision of Dr. Adam Głazaczow from the Institute of Environmental Studies, Adam Mickiewicz University in Poznań. Altogether 65 laboratory measurements have been conducted.

\section{Textile raw material}

No traces of parched organic substance have been preserved in recorded negatives. It has to be predicted that the fabric was made of wool (?), and the thickness of elementary fibres is to be shaped around $0.020 / 0.024 \mathrm{~mm}$ (in warps - O) and around 0.021/0.024 $\mathrm{mm}$ (in wefts - W). Partly preserved and modified fibres (kilning and/or exploitation of the pot), which were impressed at the bottom of the negative, do not bring complete information about the original quality or contamination of raw material, which as a result makes a comparison of our measurements with results of "classical" studies of fabrics a very difficult one.

\section{Yarn}

In both analyzed cases, the yarn was twisted to the right (ZZ) - tab. 1, 2. An average thickness of threads impressed on the $10^{\text {th }}-11^{\text {th }}$ century vessel ranges from $0.327(\mathrm{O})$ to $0.404(\mathrm{~W}) \mathrm{mm}$, while on the $9^{\text {th }}-10^{\text {th }}$ century pot it ranges from $0.723(\mathrm{O})$ to $0.905(\mathrm{~W}) \mathrm{mm}$. Our observation confirms to a certain extent a practice of a thinner yarn use since the $11^{\text {th }}$ century $\mathrm{AD}$, also at the Góra settlement. Thus, one has to acknowledge that, within the context of other discoveries in Poland, both "older" and "younger" threads were sufficiently good considering their utilitarian value.

\section{Fabric}

In analyzed negatives a linen weave $1 / 1-$ fig. 2: 3, 4 has been observed. It comes probably from the fabric, type 1, class III and IV. These are to be included to the poorest quality fabrics, which were probably produced on the vertical weighs employed loom(?). 
Studies of "pottery" fabrics, which are often completely ignored by scholars, have already brought about certain results that are a very good starting point for further attempts. The worst - from the contemporary point of view - category of rags used in potter's and/or tile-stove maker's workshop waits for a more complete analysis. These studies will be continued.

Translated by Arkadiusz Marciniak 